Int. J. Morphol.,

33(3):883-887, 2015.

\title{
Structure and Histophysiological Considerations on the Arterial Wall of the Dog
}

\author{
Estructura y Aspectos Histofisiológicos de la Pared Arterial del Perro
}

\author{
Antonio M. Orsi*; Raquel F. Domeniconi**; Josiane M. de Mello*** \& Caio S. G. Spilla****
}

ORSI. A. M.; DOMENICONI, R. F.; MELLO, J. M. \& SPILLA, C. S. G. Structure and histophysiological considerations on the arterial wall of the dog. Int. J. Morphol., 33(3):883-887, 2015.

SUMMARY: This paper described the architecture of the dog aortic arterial wall focused in the ascendant; thoracic descendent, and abdominal parts of the aorta. Furthermore, in this study we analyzed the wall structure of the right external iliac artery and the left vertebral artery of dog aiming to compare their architectural patterns with the aortic wall mainly in abdominal aortic part, which was structured by a mixed muscular and connective matrix equilibrated elements. The variables analyzed were the thickness of each mural layer; the number of elastic lamellae, mainly localized into the medial layer structure, and the diameters of each aortic segment. The aortic structure showed a typical elastic pattern in the ascendant and descendant thoracic parts, but in its abdominal segment a lesser presence of elastic lamellae permitted to classify it with a mixed mural composition. The aortic segments mainly presented variable amounts of smooth muscle cells and connective matrix assuming a meshwork pattern. Furthermore, smooth muscle cells were seen intermingled with connective lamellae and fibers forming the complex meshwork related, which certainly helped to guarantee the aortic mural integrity during the aortic blood flow.

KEY WORDS: Artery; Mural structure; Histophysiology; Dog.

\section{INTRODUCTION}

Anatomic texts when referring to mural aortic architecture and describing the large aortic ramifications classify these vessels with an elastic pattern. The large arteries directly branching from aorta, such as the carotid and subclavian arteries, were structured by several elastic lamellae and fibers in their coats. Also, the parietal and visceral collaterals originated from those vessels, e.g. the vertebral and external iliac arteries, presented a relative major number of smooth muscle cells in their parietal coats (Viegas et al., 2004; Martini et al., 2009; Tortora \& Grabowisky, 2012). Perhaps, some papers suggested presence of a mixed structure from the abdominal part of aorta, in which equilibrium in the mural distribution of smooth muscle cells and connective matrix components were verified, with a minor number of elastic lamellae and fibers occurring (Viegas et al., 2001; Orsi et al., 2004; Mello et al., 2004, 2007, 2009). This last distal aortic wall composition apparently supports one of the causes for abdominal aortic aneurysm pathology (MacSweeney et al., 1992; Henney et al., 1993).
Also observed on the mural aortic architecture of dog was the presence of membranous elastic tissue also disposed as lamellae and fibers (Song \& Roach, 1985; Orsi et al.). The predominance of aorta elastic tissue in mammals is accomplished by interconnections among elastic lamellae and connective dense lamellae throughout connective dense fibers. Complex networks were seen, including smooth muscle cells intermingled with elastic and connective dense lamellae and fibers, mainly disposed into the aortic medial layer structure (Tindall \& Svendsen, 1982; Clark \& Glagov, 1985; Hass et al., 1991; Awal et al., 1995; Viegas et al., 2001; Orsi et al.; Mello et al., 2004, 2007, 2009).

Besides these reports the morphometry of some parameters concerning the aortic mural structure had not been described at comparative level, such as: (1) the medium thicker of the aortic layers at segmental levels from the aorta transit inside the thoracic and abdominal cavities; (2) the medium number of elastic lamellae presented into the medial aortic layer according to segmental transit pattern; (3) a

*Professor Titular Emérito, Departamento de Anatomia, Universidade Estadual Paulista (UNESP), Botucatu, Brazil.

**Professor Assistente, Doutor do Departamento de Anatomia, Instituto de Biociências, Universidade Estadual Paulista (UNESP), Botucatu, Brazil.

***Professor Adjunto, Departamento de Morfofisiologia, Universidade Estadual de Maringá, Maringá, Brazil.

****Docente Especialista em Histologia, Universidade de Marília, Marília, Brazil. 
comparative analysis among those parameters referred and similar patterns observed into the layers of the external iliac artery, and (4) a theoretical analysis made between the structural physiology of the aorta wall and the architectural mixed wall pattern of the right iliac artery and left vertebral artery. Both the last arteries presented equilibrated smooth muscle cells and connective elements in their layers (Evans, 1993; Viegas et al., 2001, 2004; Martini et al.; Tortora \& Grabowisky). The aim of this study was to analyze these parameters.

\section{MATERIAL AND METHOD}

Ascendant aorta (T2-T3 level, 1th position or P1), descendant thoracic aorta (T7-T8 level, 2th position, or P2), abdominal aorta (L6-L7 level, 3th position or P3), and right external iliac artery (at its middle part, 4th position or P4), samples were collected from ten adult mongrel dogs (Canis familiaris), of both sexes weighing $13 \mathrm{~kg}$ of average. Also, a segment of the left vertebral artery was collected from the dogs, near the origin of this artery from the left subclavian artery.

The dogs were sacrificed by intravenous injection of barbiturate salt and the arterial tree was perfused by gravity with buffered formalin (0.1 phosphate buffer, $\mathrm{pH} 7.2)$ applied at a continuous flow in all the dogs, whose collected materials were destined for light microscopy studies.

The materials were routinely processed for histology by embedding of the tissues in Paraplast resin. Five to seven micrometre sections were taken and stained with HE, Van Gieson's Picrofuchsin, hydrochloric orcein, and Calleja and Masson trichromes (Lillie, 1965). A part of the microscopic materials being four histological sections of the aorta, focusing on the three positions (P1, P2, and P3), was considered in all the dogs, whose data were submitted at random measurements of the aortic thickness. Afterwards, the same number of histological sections from the right external iliac artery (P4), was submitted to the same measurement used from the aorta. Two conditions ( $\mathrm{C} 1$ and $\mathrm{C} 2$ ) were adopted from the measurements of the arterial walls, referring to the thickness of the inner plus medial layers $(\mathrm{C} 1)$ and the thickness of the adventitial layer (C2).

The thickness of the aortic layers was measured, considering the two conditions $(\mathrm{C} 1$ and $\mathrm{C} 2)$, which were established in transverse histological sections $(5 \mu \mathrm{m})$, stained with Masson trichrome from each aortic segment (positions P1 from P3), using a 10x ocular micrometer and a 20x objective under an Olympus BH-2 microscope, and also using an image analysis system (Zeiss KS-300). Similar procedures were taken from the right external iliac artery segment (position P4), as well as to measure the vertebral arterial coats $(\mathrm{C} 1$ and $\mathrm{C} 2$ conditions).

The Zeiss KS-300 system was also used for elastic lamellae counts made in aortic and external iliac artery segments, following measurements of the arterial diameters of these vessels realized in regular round shaped samples of each vessel analyzed. The numerical data obtained of the segmental thickness of the aortic wall and external iliac artery layers were analyzed by parametric quantitative method. The parametric data were employed to yield the median values of the arterial mural layer thickness.

\section{RESULTS AND DISCUSSION}

The medial layer of the dog aorta was thicker than the other layers and showed the greater thickness in the ascendant thoracic segment (Fig. 1), such as was described in other mammal, also including the aorta of the dog (Viegas et al., 2001; Orsi et al.; Mello et al., 2004, 2007, 2009). Inside the ascendant aortic wall a luminal blood flow was observed which shows a vortex pattern as a consequence of the left ventricular systolic pressure (Melbin \& Detweiler, 1998).

An intermediary mural thickness was observed from the aortic descendant thoracic segment, followed by a lesser mural thickness showed in the aortic abdominal segment (Fig. 1), according to the last authors cited. The last two aortic segments showed a lamellar blood flow into the aorta luminal compartment, in which blood cells formed organized spatial arrangements surrounded by the blood plasma, which helps to guarantee an adequate renal perfusion (Melbin \& Detweiler).

Referring to the histological findings verified to the combination formed by the inner layer plus the medial layer from the aorta segments ( $\mathrm{C} 1$ condition, Fig. 1), similarly described in other mammals (Viegas et al., 2001; Mello et al., 2004, 2009), could be considered the radial distension verified in aortic wall during the impact of the systolic pressure of the heart left ventricle (Tindall \& Svendsen; Sthebens, 1996).

Apparently, the interrelations established among smooth muscle cells and connective lamellae and fibers were prevalent, mainly disposed as meshwork into the aortic medial and adventitial layers (Wolinsky \& Glagov, 1967; Tindall \& Svendsen; Clark \& Glagov; Hass et al.; Awal et al.; Viegas et al., 2001; Orsi et al.; Mello et al., 2004, 2007, 2009). Those intermingled connections established between mural elastic and dense collagen fibers and lamellae, and also with smooth 


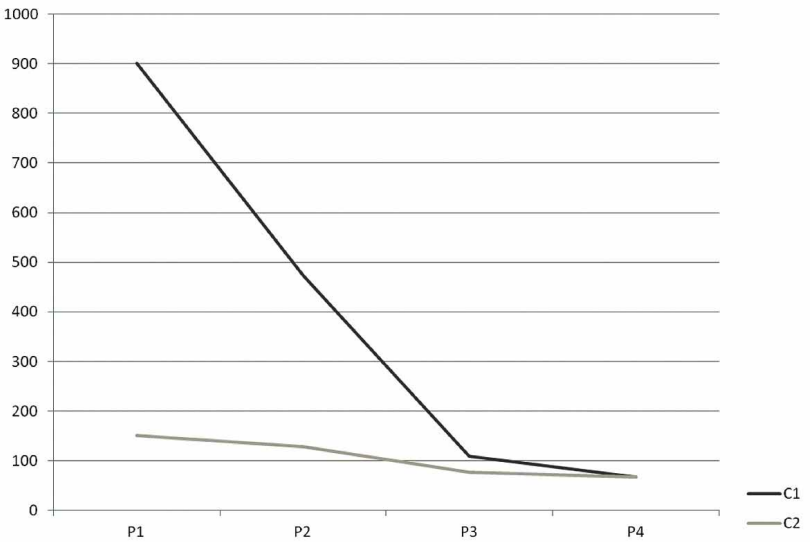

Fig. 1. Diagram representative of the thickness of the dog aorta at the level of the segments P1 to P3 and also representation of the thickness of the dog right iliac external artery 4th position(P4), analyzed under the conditions $\mathrm{C} 1$ and $\mathrm{C} 2$. $\mathrm{P} 1$ to $\mathrm{P} 3$ represented the segmental levels, or parts, in which aortic segments were studied, being P1: ascendant aortic (T2-T3 level) segment; P2: descendant thoracic segment (T7-T8 level), and P3: aortic abdominal segment ((L6-L7 level). P4 represented the middle part of the external iliac artery in which transverse arterial segments were collected. C1 represented the first condition referring the arterial layers studying the thickness of the inner coat plus the medial coat. C2 was the thickness of the arterial adventitial layer.

muscle cells, help guarantee the aortic mural integrity, besides the alternative mechanic impacts suffered by the aortic wall during cardiac cycle (Sthebens; Melbin \& Detweiler; Mulroney $\&$ Meyers, 2010).

The median value of elastic lamellae verified into the aortic medial layer decreased from the ascendant thoracic segment to the abdominal infra kidney segment. A median value of 40 concentric elastic lamellae was observed (position 1 , or P1), into the medial layer of the ascendant aortic segment. This number was followed by 30 elastic lamellae (position 2, or P2) localized into the medial layer of the descendant thoracic aorta, and a lesser number of 15 elastic lamellae (position 3, or P3), occurred in the descendant abdominal part of aorta (Fig. 2).

Furthermore, the aortic diameters accomplished a similar pattern, with median values of $10 \pm 2 \mathrm{~mm}$ in the ascendant segment; $8 \pm 1.2 \mathrm{~mm}$ in the descendant thoracic part, and $6 \pm 1.4$ $\mathrm{mm}$ in the abdominal segment of the aorta. The adventitial aortic layer in dog appeared as a thinner coat in all the aortic segments focused; including the mural structure of the right external iliac artery (Fig. 1).

The adventitial layer was formed by lamellar and fibrous collagen and elastic tissue disposed with transverse, longitudinal and oblique orientations, with interconnecting elastic fibers that joined disperse elastic and collagen lamellae, whose general disposition was observed as a framework composition. Similar pattern was described previously from the dog itself (Song \& Roach); concerning the last histological pattern described, it was generally observed in mammals, according to the authors here cited. Nevertheless, it was necessary to consider from the aortic mural histology some species specific peculiarities, especially characterized in laboratory rodents (Mello et al., 2004); dog (Song \& Roach; Orsi et al.), and in tufted capuchin monkey (Mello et al., 2009).

The occurrence of a minor number of elastic medial lamellae in the abdominal segment of aorta was previously verified in some mammals (Viegas et al., 2001; Mello et al., 2004, 2009), including man (Simionescu \& Simionescu, 1981), and dog (Orsi et al.). This could be associated with a lesser diameter of the aorta in this segment (Fig. 1). However, no description had considered this last hypothesis, On the other hand, a lesser number of elastic tissue in distal mural aorta level, seemed to be related to the pathology of human aortic aneurysm disease (MacSweeney et al.; Henney et al.).

As was described in the introduction, referring to the minor number of mural elastic lamellae observed in the abdominal (distal) part of the dog artery, there are similar reports of the human aorta (Simionescu \& Simionescu; Martini et al.). Both these observations based on the decrease of the connective matrix elements and scarcity of smooth muscle cells arrangements (or networks). This wall pattern was described in aorta medial layer from older men. It could be one of the main causes from the distal aortic aneurysm etiology in human being (MacSweeney et al.; Henney et al.).

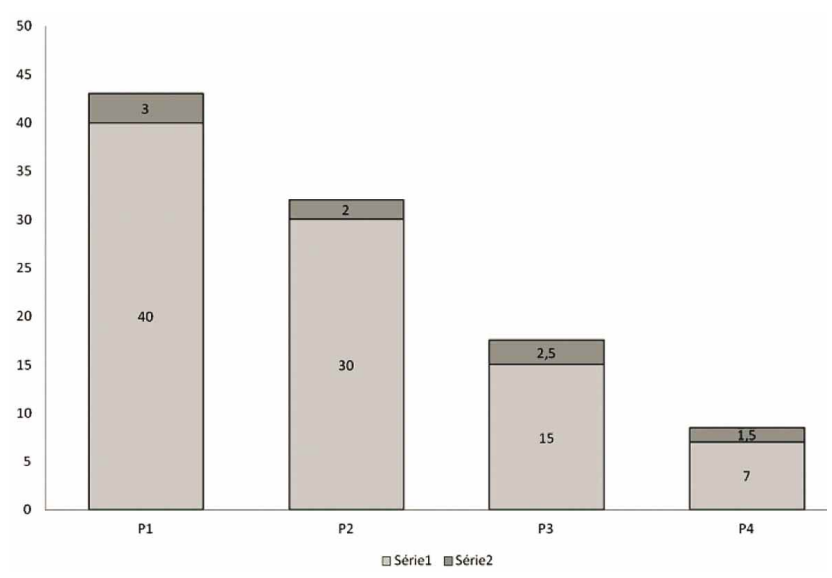

Fig. 2. Diagram representative of the median values of elastic lamellae presented in the medial layers of aorta, at the level of the segments (P1 to P3), and also representation of median values from elastic lamellae of the medial layer in right iliac external artery (P4). The data were analyzed under the conditions $\mathrm{C} 1$ and $\mathrm{C} 2$. See legend of Figure 1 to see the explanation of the positions (P1 to $\mathrm{P} 4)$, and conditions ( $\mathrm{C} 1$ to $\mathrm{C} 2$ ). 
An expressive decrease in number of lamellar arrangement occurred into the medial layer structure of the right external iliac artery (Fig. 2). This last artery with median value of seven elastic lamellae into its medial layer, was considered a vessel with predominance of mural smooth muscle cells structure. Concerning the median diameter observed from the right external iliac artery, it was about $2.7 \pm 0.5 \mathrm{~mm}$. Moreover, a similar structure comparatively with the external iliac artery was seen for the left vertebral artery of the dog, which also showed a muscular pattern. Muscular arterial structure and topology have been described in specific literature, mainly in man (Simionescu \& Simionescu; Martini et al.; Tortora \& Grabowsky).

The external iliac artery and also the vertebral artery were distributive vessels. In both these arteries the luminal compartment required ordinate blood flow, necessary to assure a better distribution of blood components. Specific blood supply was made to the pelvic limbs by the external iliac artery and its branches, as well as a main part of the central neural irrigation supplied by the vertebral artery (Evans; Martini et al.; Tortora \& Grabowsky).
CONCLUSION. The arterial wall observed in the aortic topographic segments, of the adult dog, showed a similar pattern from the mural layers arrangements, which were reproduced in general terms, from the right external iliac artery and from the left subclavian artery in this species. The mural histologic pattern was represented by an intermingled meshwork of smooth (contractile) muscle cells and connective elements (passive formations), observed mainly into the medial layer building of each artery analyzed. Obviously, aorta was a classic elastic blood vessel in their proximal (ascendant) and descendant thoracic segments, whose blood flow inside their vascular lumen presented great pressure level, demanding major reinforcement of the aortic wall. However, in the abdominal post renal aortic part the mural structure presented a mixed and equilibrated amounts of smooth muscle cells and connective matrix. A lesser number of elastic lamellae and elastic and connective dense fibers was verified in the abdominal aorta segment. This pattern was similar from the building of the other two muscular (predominat) arteries, studied for comparison among the mural architecture of the blood vessels focused.

ORSI. A. M.; DOMENICONI, R. F.; MELLO, J. M. \& SPILLA, C. S. G. Estructura y aspectos histofisiológicos de la pared arterial del perro. Int. J. Morphol., 33(3):883-887, 2015.

RESUMEN: El objetivo de este trabajo fue describir la estructura histológica de la aorta del perro adulto, a través del análisis morfométrico. Fueron estudiados los tres segmentos de la aorta, ascendente y descendente torácicos, y el segmento abdominal inferior a los riñones. Esta última porción presentó un patrón estructural mixto, con tejido muscular liso y conectivo, con equilibrio entre las células musculares lisas y el componente mural tipo estroma, con elementos fibrosos y laminillas elásticas. En las otras partes de la aorta, se observó el clásico patrón elástico en la estructura mural, con una mayor proporción de los componentes activos (musculares lisos) que los pasivos, o sea, laminillas y fibras conectivas. El número de las laminillas elásticas fue decreciente desde la aorta ascendente en dirección a la parte abdominal de la aorta. Los diámetros de los tres segmentos tiñeron de manera similar. La comparación entre la estructura mural de la aorta y la histología de la arteria iliaca interna derecha y arteria subclavia izquierda, ambas musculares, fueron analizadas de manera objetiva, encontrando diferencias en el patrón mural aórtico, principalmente en el segmento aórtico terminal.

PALABRAS CLAVE: Arteria; Estructura mural; Histofisiología; Perro.

\section{REFERENCES}

Awal, M. A.; Matsumoto, M. \& Nishinakagawa, H. Morphometrical changes of the arterial walls of main arteries from heart to the abdomino-inguinal mammary glands of rat from virgin through pregnancy, lactation and post-weaning. J. Vet. Med. Sci., 57(2):251-6, 1995.

Clark, J. M. \& Glagov, S. Transmural organization of the arterial media. The lamellar unit revisited. Arteriosclerosis, 5(1):1934, 1985.

Evans, H. E. Miller's Anatomy of the Dog. 3rd ed. Philadelphia, Saunders, 1993.
Haas, K. S.; Phillips, S. J.; Comerota, A. J. \& White, J. V. The architecture of adventitial elastin in the canine infrarenal aorta. Anat. Rec., 230(1):86-96, 1991.

Henney, A. M.; Adiseshiah, M.; Poulter, N.; MacSweeney, S. T. R.; Greenhalgh, R. M. \& Powell, J. T. Abdominal aortic aneurysm. Abdominal aortic aneurysm. Report of a meeting of physicians and scientists, University College London Medical School. Lancet, 341(8839):215-20, 1993.

Lillie, R. D. Histopathologic Technic and Practical Histochemistry. New York, Mc Graw-Hill, 1965. 
MacSweeney, S. T.; Young, G.; Greenhalgh, R. M. \& Powell, J. T. Mechanical properties of the aneurysmal aorta. Brit. $J$. Surg., 79(12):1281-4, 1992.

Martini, F. H.; Timmons, M. J. \& Tallitsch, R. B. Anatomia Humana. 6a ed. Porto Alegre, Artmed, 2009.

Melbin, J. \& Detweiler, D. K. Sistema cardiovascular e fluxo sanguíneo. In: Swenson, M. J. \& Reece, W. O. Dukes: Fisiologia dos Animais Domésticos. 11a. ed. Rio de Janeiro, Guanabara Koogan, 1998. pp.57-80.

Mello, J. M.; Orsi, A. M.; Padovani, C. R.; Matheus, S. M. M. \& Eleutério, M. L. Structure of the aortic wall in the guinea pig and rat. Braz. J. Morphol. Sci., 21(1):35-8, 2004.

Mello, J. M.; Torrejais, M. M.; Matheus, S. M. M.; Domeniconi, R. F.; Simões, K. \& Orsi, A. M. Características ultraestruturais do segmento abdominal da aorta de rato albino. Acta Sci. Biol. Sci. (Maringa), 29(4):343-8, 2007.

Mello, J. M.; Orsi, A. M.; Domingues, R. J. S.; Molinari, S. L. \& Araújo, A. M. M. de Arquitetura da parede vascular de segmentos torácico e abdominais da aorta de macaco prego (Cebus apella). Braz. J. Vet. Res. Anim. Sci. (São Paulo), 46(1):40-7, 2009.

Mulronney, S. E. \& Meyers, A. K. Netter. Bases da Fisiologia. Rio de Janeiro, Elsevier, 2010. pp.107-12.

Orsi, A. M.; Stefanini, M. A.; Crocci, A. J.; Simões, K. \& Ribeiro, A. A. Some segmental features on the structure of the aortic wall of the dog. Anat. Histol. Embryol., 33(3):131-4, 2004.

Simionescu, N. \& Simionescu, M. O Sistema Cardiovascular. In: Weiss, L. \& Greep R. O. (Eds). Histologia. 4a ed. Rio de Janeiro, Guanabara Koogan, 1981. pp.311-61.

Song, S. H. \& Roach, M. R. A morphological comparison of aortic elastin from five species as seen with the scanning electron microscope. Acta Anat. (Basel), 123(1):45-50, 1985.

Sthebens, W. E. Structural and architectural changes during arterial development and the role of hemodynamics. Acta Anat. (Basel), 157(4):261-74, 1996.

Tindall, A. R. \& Svendsen, E. Intimal folds of the rabbit aorta. Acta Anat. (Basel), 113(2):169-77, 1982.

Tortora, G. J. \& Grabowski, S. R. Corpo Humano: Fundamentos de Anatomia e Fisiologia. 8a. ed. São Paulo, Artmed, 2012.

Viegas, K. A. S.; Orsi, A. M.; Matheus, S. M. M.; Francía-Farje, L. A. D.; Orsi, D. C. \& Mello, J. M. Características estructurales de la aorta de conejo (Oryctolagus cuniculus). Rev. Chil. Anat., 19(2):131-7, 2001.
Viegas, K. A. S.; Orsi, A. M.; Simões, K. \& Crocci, A. J. Histoarquitetura das artérias subclávia e vertebral esquerdas no cão (Canis familiaris). Biosci. J. (Uberlândia), 20(2):1639, 2004.

Wolinsky, H. \& Glagov, S. A lamellar unit of aortic medial structure and function in mammals. Circ. Res., 53(4): 99-111, 1967.

\author{
Correspondence to: \\ Antonio Marcos Orsi \\ Professor Titular Emérito \\ Departamento de Anatomia \\ Universidade Estadual Paulista (UNESP) \\ Botucatu, São Paulo \\ BRAZIL
}

Email: amorsi47@gmail.com

Received: 08-03-2015

Accepted: 08-05-2015 